\title{
Cesium Hydroxide Fusion Dissolution of Analytical Reference Glass-1 in Both Powder and Shard Form
}

by

C. J. Coleman

Westinghouse Savannah River Company

Savannah River Site

Aiken, South Carolina 29808

W. A. Spencer

DOE Contract No. DE-AC09-96SR18500

This paper was prepared in connection with work done under the above contract number with the U.S. Department of Energy. By acceptance of this paper, the publisher and/or recipient acknowledges the U.S. Government's right to retain a nonexclusive, royalty-free license in and to any copyright covering this paper, along with the right to reproduce and to authorize others to reproduce all or part of the copyrighted paper.

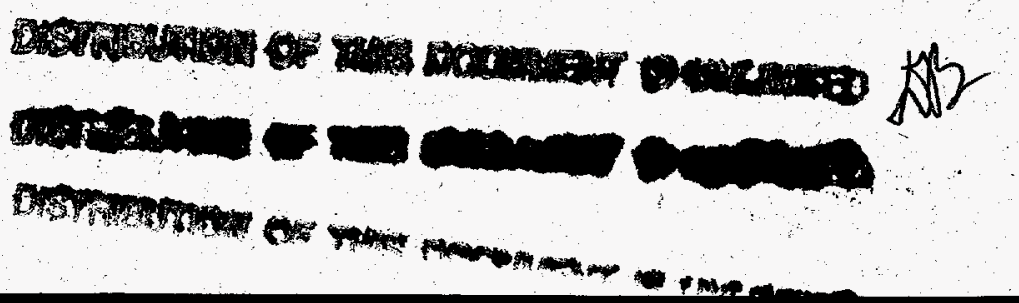




\section{DISCLAIMER}

Portions of this document may be illegible electronic image products. Images are produced from the best available original document. 


\section{DISCLAIMER}

This report was prepared as an account of work sponsored by an agency of the United States Government. Neither the United States Government nor any agency thereof, nor any of their employees, makes any warranty, express or implied, or assumes any legal liability or responsibility for the accuracy, completeness, or usefulness of any information, apparatus, product, or process disclosed, or represents that its use would not infringe privately owned rights. Reference herein to any specific commercial product, process, or service by trade name, trademark, manufacturer, or otherwise does not necessarily constitute or imply its endorsement, recommendation, or favoring by the United States Government or any agency thereof. The views and opinions of authors expressed herein do not necessarily state or reflect those of the United States Government or any agency thereof.

This report has been reproduced directly from the best available copy.

Available to DOE and DOE contractors from the Office of Scientific and Technical Information, P.O. Box 62, Oak Ridge, TN 37831; prices available from (615) 576-8401.

Available to the public from the National Technical Information Service, U.S. Department of Commerce, 5285 Port Royal Road, Springfield, VA 22161. 
Westinghouse Savannah River Company

Savannah River Technology Center

April 21, 1998
WSRC-TR-98-00124

Page 1 of 16

Rev. 0

Keywords:

Glass Dissolutions, Elemental Analyses

TO: $\quad$ A.L. Blancett, 773-A

FROM: C.J. Coleman, 773-A and W.A. Spencer, 773-41A

\section{Cesium Hydroxide Fusion Dissolution of Analytical Reference Glass-1 in both Powder and Shard Form}

\section{Distribution}

M. K. Andrews, 773-A

R.S. Beck, 704-28S

D.R. Best, 773-A

N.E. Bibler, 773-A

P.F. Cloessner, 773-A

P.T. Deason, 773-A

T.L. Fellinger, 773-A

P.E. Filpus-Luyckx, 773-41A
J.R Harbour, 773-43A

J.C. Hart, 773-A

C.A. Jantzen, 773-A

S.L. Marra, 704-25S

K.M. Marshall, 773-A

D.K. Peeler, 773-43A

R.F. Schumacher, 773-43A

R.B. Spencer, 210-S 
Westinghouse Savannah River Company

Savannah River Technology Center

April 21, 1998
WSRC-TR-98-00124

Page 2 of 16

Rev. 0

Keywords: Glass Dissolutions,

Elemental Analyses

TO:

A.L. Blancett, 773-A

C.S.Cremen

Wajpene?

FROM: C.J. Coleman, 773-A and W.A. Spencer, 773-41A

\section{Cesium Hydroxide Fusion Dissolution of Analytical Reference Glass-1 in both Powder and Shard Form}

\section{Summary}

$\mathrm{CsOH}$ has been shown to be an effective and convenient dissolution reagent for Analytical Reference Glass-1 (ARG-1). This glass standard was prepared from nonradioactive DWPF Start-up Glass. Therefore, its composition is similar to DWPF product glass and many of the glass matrices prepared at SRTC.

The principal advantage of the $\mathrm{CsOH}$ fusion dissolution is that the reagent does not add the alkali metals $\mathrm{Li}, \mathrm{Na}$, and $\mathrm{K}$ usually needed by SRS customers. Commercially available $\mathrm{CsOH}$ is quite pure so that alkali metals can be measured accurately, often without blank corrections. $\mathrm{CsOH}$ fusions provide a single dissolution method for applicable glass to replace multiple dissolution schemes used by most laboratories. For example, SRTC glass samples are most commonly dissolved with a $\mathrm{Na}_{2} \mathrm{O}_{2}-\mathrm{NaOH}$ fusion (ref.1) and a microwave-assisted acid dissolution with $\mathrm{HNO}_{3}-\mathrm{HF}-\mathrm{H}_{3} \mathrm{BO}_{3}-\mathrm{HCl}$ (ref.2). Other laboratories use fusion methods based on $\mathrm{KOH}, \mathrm{LiBO}_{2}$, and $\mathrm{Na}_{2} \mathrm{CO}_{3}$. The $\mathrm{CsOH}$ fusion approach reduces by half not only the work in the dissolution laboratory, but also in the spectroscopy laboratories that must analyze each solution.

Experiments also revealed that glass shards or pellets are rapidly attacked if the flux temperature is raised considerably above the glass softening point. The softening point of ARG-1 glass is near $650^{\circ} \mathrm{C}$. Fusions performed at $750^{\circ} \mathrm{C}$ provided complete dissolutions and accurate elemental analyses of shards. Successful dissolution of glass shards was demonstrated with $\mathrm{CsOH}, \mathrm{Na}_{2} \mathrm{O}_{2}, \mathrm{NaOH}, \mathrm{KOH}$, and $\mathrm{RbOH}$. Ability to dissolve glass shards is of considerable practical importance. Crushing glass to a fine powder is a slow and tedious task, especially for radioactive glasses dissolved in shielded cells. $\mathrm{CsOH}$ fusion of glass powder or shards is a convenient, cost-effective dissolution scheme applicable in SRTC, the DWPF, and the commercial glass industry. 


\section{Principal Experimental Findings}

WSRC-TR-98-00124

Page 3 of 16

Rev. 0

- $\mathrm{CsOH}$ fusion dissolutions of ARG-1 glass were analyzed to within 5\% of the reference value for all major elements (elements above 0.5 weight $\%$ in the glass). Analytical precision was also excellent, better than 5\% relative standard deviation for major elements.

- No significant differences in the elemental analyses of $\mathrm{CsOH}$ and $\mathrm{Na}_{2} \mathrm{O}_{2}$ fusions were found except for $\mathrm{Ca}$ values. The $\mathrm{Na}_{2} \mathrm{O}_{2}$ fusions gave high biases on one set of dissolutions.

- No significant differences in the analyses of ARG-1 powder and pellets were found with both $\mathrm{CsOH}$ and $\mathrm{Na}_{2} \mathrm{O}_{2}$ fusions (Ca excepted for one set of $\mathrm{Na}_{2} \mathrm{O}_{2}$ fusions).

- ARG-1 glass pellets and shards were rapidly attacked by $\mathrm{NaOH}, \mathrm{KOH}, \mathrm{RbOH}, \mathrm{CsOH}$, and $\mathrm{Na}_{2} \mathrm{O}_{2}$ at $750^{\circ} \mathrm{C}$ to provide complete dissolution of the low surface area glass samples.

- Crucible melts of ARG-1 glass were shattered within the crucible to yield small glass shards. Analyses of the shards were of high accuracy and precision, indicating that crucible melt samples were homogeneous and shard dissolutions were successful.

- No significant temperature effect was found in the range $500-750^{\circ} \mathrm{C}$ for $\mathrm{CsOH}$ fusions of ARG-1 powder.

- Blank levels of $\mathrm{K}$ and $\mathrm{Na}$ were near or below the detection limit of spectroscopy methods (ICP-atomic emission spectroscopy and atomic absorption spectroscopy). Accurate $\mathrm{K}$ and $\mathrm{Na}$ values were obtained without using blank corrections. Also, a trace of Ti impurity was in the $\mathrm{CsOH}$. Ti determinations of ARG-1 glass were accurate, despite the impurity.

- ICP-AES determinations were made after calibrating on $2 \% \mathrm{HNO}_{3}$ standards. Accurate elemental analyses obtained from these standards indicate that matrixmatched calibration standards may be unnecessary.

- Dilution and acidification steps of alkali fusions were performed by dropping the entire crucible into a known volume of water and then adding a known volume of acid. This technique avoids the transfer spills and errors common with fusion dissolutions. The simplified scheme is more convenient for fusions performed remotely in shielded cells. Transfers made with manipulators are prone to transfer errors. High accuracy on samples dissolved this way indicates that the technique is sound. 
WSRC-TR-98-00124

Page 4 of 16

Rev. 0

\section{Limitations}

The $\mathrm{CsOH}$ method is not being touted as a panacea that will work for every element in every glass matrix. CsOH is a very strong base that attacks the silica framework of glass under fusion conditions. Oxidized metals liberated from the glass can then be dissolved by acid addition. However, $\mathrm{CsOH}$ lacks the strong oxidizing power of $\mathrm{Na}_{2} \mathrm{O}_{2}$. $\mathrm{CsOH}$ may not be effective for determinations of reduced noble metals or elements in spinel crystals in the glass sample. The $\mathrm{CsOH}$ fusion also may not be effective for measuring $\mathrm{P}$ in high phosphate glasses.

\section{Introduction}

Having to use at least two different dissolution procedures for glass analyses has long been a bane to the efficiency of dissolution and spectroscopy laboratories. The effect on dissolution laboratories is obvious; the effect on spectroscopy laboratories is more subtle. Spectroscopy laboratories not only analyze each dissolution, but frequently also maintain separate calibration standards for each dissolution method. Considerable time is spent preparing multiple sets of standards and calibrating instruments with these standards. Multiple dissolution schemes more than double the spectroscopy work on solid samples.

$\mathrm{CsOH}$ fusions effectively dissolve the DWPF glass matrix that constitutes at least $80 \%$ of the glass samples analyzed in SRTC the last 15 years. Experimental results to date indicate that the $\mathrm{CsOH}$ fusion method would save time and money for applicable programs. Development of the $\mathrm{CsOH}$ method and potential applications to SRS programs are discussed in this report.

\section{Experimental}

Crystalline cesium hydroxide monohydrate with excellent purity was purchased from Aldrich Chemical $\mathrm{Co}$. The cost of $\mathrm{CsOH}$ when bought in $250 \mathrm{~g}$ bottles is less than a dollar per gram. $\mathrm{CsOH} \bullet \mathrm{H}_{2} \mathrm{O}$ is quite deliquescent and must be placed in the furnace shortly after weighing to avoid excess water absorption.

The CsOH fusion method is analogous to other basic fluxes used in SRTC (ref.1). About $0.28 \mathrm{~g}$ of powdered glass or glass shards and $2.8 \mathrm{~g}$ of $\mathrm{CsOH}$ are weighed into a $\mathrm{Zr}$ or Ni crucible. The mixture is fused by heating in a muffle furnace for 5 minutes at $600^{\circ} \mathrm{C}$ for powdered glass, or 5 minutes at $750^{\circ} \mathrm{C}$ for glass shards or pellets. After cooling for about two minutes, the crucible is dropped into a $1 \mathrm{~L}$ wide-mouth plastic bottle containing 250 $\mathrm{ml}$ of de-ionized water (measured in a volumetric flask) and one or two drops of $30 \%$ $\mathrm{H}_{2} \mathrm{O}_{2}$. The $\mathrm{H}_{2} \mathrm{O}_{2}$ is used to turn the purple solution into a pale yellow solution so that the solution can be inspected for complete dissolution of the glass. The bottle is swirled to splash enough water into the crucible to sink it. It is important to give the flux matrix 
WSRC-TR-98-00124

Page 5 of 16

Rev. 0

enough time to dissolve in water before the concentrated acid solution is added. If the acid is added too soon, silica may precipitate from the strong acid solution. For ARG-1 glass dissolutions, the flux residue was allowed to contact the water solution for 10 minutes with frequent swirling of the bottle. The $25 \mathrm{ml}$ of acid (measured out with an accurate pipette) was then added slowly, with occasional swirling of the bottle. The solution should be clear and ready for analysis after all the acid is added.

ARG-1 glass was originally prepared by Ferro Corporation to serve as DWPF Start-up Glass. A $110 \mathrm{~kg}$ sample of DWPF Start-up Glass was sent to Corning Incorporated. Corning ground and sieved the glass to -100 mesh. Corning then performed a total of 36 elemental analyses to establish the glass composition (ref. 3 ). This glass was also used as the unknown in Analytical Round Robin-6 (ref. 4). After Round Robin-6 was complete in $1991, \mathrm{a} \mathrm{kg}$ of the powdered glass was sent to both SRTC and the DWPF Laboratory. It has since been the most commonly used glass standard at SRS.

Solid pieces of ARG-1 glass were prepared two different ways. To ensure that glass heterogeneity would not affect results, the first method used was to weigh about $0.28 \mathrm{~g}$ of powdered ARG-1 glass into a Pt crucible and heat at $110{ }^{\circ} \mathrm{C}$ for 10 minutes to re-melt the glass. The glass pellet that formed upon cooling was transferred from the Pt crucible to a $\mathrm{Zr}$ crucible and dissolved with fusion methods. The other method was to add $5 \mathrm{~g}$ of ARG-1 glass to the $\mathrm{Pt}$ crucible and heat at $1100^{\circ} \mathrm{C}$ for 20 minutes. The amount chosen was to simulate the DWPF process control analyses in which the contents of $14 \mathrm{ml}$ vials are vitrified to yield about 5-6 $\mathrm{g}$ of glass. The glass disk was crushed into small shards by using a ceramic pestle in the crucible. These shards were sub-sampled, transferred to a $\mathrm{Zr}$ crucible, dissolved, and analyzed.

\section{Discussion}

\section{Accuracy and Precision of ARG-1 Elemental Analyses following CsOH and $\mathrm{Na}_{2} \mathrm{O}_{2}$ Fusions}

Elemental analyses of ARG-1 glass powder following dissolutions by CsOH and $\mathrm{Na}_{2} \mathrm{O}_{2}$ fusions are compiled in Table 1. Both accuracy and precision of the analyses were excellent except for the $\mathrm{Ca}$ determination following the $\mathrm{Na}_{2} \mathrm{O}_{2}$ fusions. The source of the high bias (1.17 weight \% measured versus 1.02 weight \% standard value) is not known, but batches of $\mathrm{Na}_{2} \mathrm{O}_{2}$ occasionally contain traces of $\mathrm{Ca}$ impurity. For all other elements with concentrations at least 0.5 weight $\%$ in the glass, the measured concentrations were within 5\% relative of the standard concentrations. Analytical precision was better than 5\% relative standard deviation (\% RSD) for elements over 0.5 weight $\%$ in the glass. 
WSRC-TR-98-00124

Page 6 of 16

Rev. 0

$\mathrm{CsOH}$ and $\mathrm{Na}_{2} \mathrm{O}_{2}$ fusions were performed and analyzed in tandem as further method validation. $\mathrm{Na}_{2} \mathrm{O}_{2}$ is the most commonly used fusion reagent for dissolving glass. Close agreement between $\mathrm{CsOH}$ and $\mathrm{Na}_{2} \mathrm{O}_{2}$ fusions shown in Table 1 indicates that they are equally effective for ARG-1 standard glass.

Fusions of ARG-1 glass powder were carried out at temperatures of 500,600 , and $750^{\circ} \mathrm{C}$ to determine if the high fusion temperatures needed to attack shards and pellets would have a deleterious effect on elemental analyses. We were concerned that Cs volatility at $750^{\circ} \mathrm{C}$ would carry sample from the crucible. Data compiled in Table 2 (only the $500^{\circ} \mathrm{C}$ and $750^{\circ} \mathrm{C}$ fusions are shown) indicate that $750^{\circ} \mathrm{C}$ fusions do not cause significant sample loss. The $\mathrm{B}$ determinations of the $500^{\circ} \mathrm{C}$ fusions are interesting because they matched exactly the reference value as measured by Corning. The B determinatiens on other dissolutions were about $1.5 \%$ low. Given the excellent precision of these analyses, it is possible that this effect is real and that some B is lost at $750^{\circ} \mathrm{C}$.

\section{Fusion Dissolutions of ARG-1 Glass Pellets}

DWPF simulated glass pellets and shards dissolve when the alkali flux temperature is increased to well beyond the softening point of glass. Apparently, the increased reaction rate is induced by the glass pellets softening to increase the surface area and by more favorable reaction kinetics from the higher temperatures. Glass pellet dissolutions were achieved with $\mathrm{CsOH}, \mathrm{Na}_{2} \mathrm{O}_{2}, \mathrm{NaOH}, \mathrm{KOH}$, and $\mathrm{RbOH}$. Both $\mathrm{CsOH}$ and $\mathrm{RbOH}$ share the advantage of not being a Li, $\mathrm{Na}$, or $\mathrm{K}$ salt. However, $\mathrm{RbOH}$ is inferior to $\mathrm{CsOH}$ because it contains more alkali impurities, is less convenient to use, and is much more expensive.

ARG-1 powdered glass was converted to glass pellets to test the reliability of directly dissolving samples with minimal surface area. The pellets were then dissolved with $\mathrm{CsOH}$ and $\mathrm{Na}_{2} \mathrm{O}_{2}$ fusions at $750^{\circ} \mathrm{C}$. Results of analyses following $\mathrm{CsOH}$ and $\mathrm{Na}_{2} \mathrm{O}_{2}$ fusions of glass pellets are compiled in Table 3 . Accuracy and precision of the glass pellet analyses were excellent and virtually identical to the ARG-1 glass powder analyses except for $\mathrm{Ca}$ measurements following the $\mathrm{Na}_{2} \mathrm{O}_{2}$ fusions. Ca measurements of the pellets did not show the same high bias seen for the glass powder.

Based on glasses tested so far, $750^{\circ} \mathrm{C}$ is the optimum temperature for attacking DWPF glass pellets and shards. Flux temperatures below $740^{\circ} \mathrm{C}$ resulted in a noticeable decline in dissolution rate. After 10 minutes at $725^{\circ} \mathrm{C}$, pellets of ARG-1 glass were remaining in the crucible. Analytical results following fusions carried out at $750^{\circ} \mathrm{C}$ were excellent, so at present there is no strong incentive to reduce flux temperatures. 
WSRC-TR-98-00124

Page 7 of 16

Rev. 0

Eliminating the glass crushing step could be important for some applications, particularly for high-activity glasses that must be dissolved in a shielded cell. Glass shard dissolutions have already been applied in the SRTC shielded cell facility. The DWPF also would benefit from direct dissolution of glass shards produced by shattering the glass wafers from in-cell crucible melts. Reduced analytical turnaround times will help increase canister production rates.

\section{Fusion Dissolution of ARG-1 Glass Shards}

Glass samples are most commonly submitted in shard form for analysis. A few shards are selected and crushed for the dissolution. To produce shards of ARG-1 glass for analysis, powdered ARG-1 was re-melted at $1100^{\circ} \mathrm{C}$ and then crushed with a ceramic pestle directly in the platinum crucible. Analyses of ARG-1 glass shards are compiled in Table 4. Accurate analyses of the glass shards indicate that the glass was homogeneous, so selecting shards did not corrupt the sample. Even if the original glass sample is heterogeneous, shattering the glass into many small shards greatly reduces the potential for sub-sampling errors.

Analyzing glass shards would improve efficiency of dissolution laboratories. Glass crushing is usually done by shattering the glass into small shards with a hammer and then using a motorized mixer mill to glass shards into a powder. Often, the sample is then sieved to separate the powder from the shards to obtain a fine powder for dissolution. Accurate analyses of shards indicate that they can be dissolved directly with fusion methods carried out at $750^{\circ} \mathrm{C}$. The tedious motorized glass crushing step would be unnecessary.

\section{Impurity Concentrations in CsOH Fusion Dissolutions}

High purity of commercially available $\mathrm{CsOH}$ is key to this method having practical applications at SRS. Very low alkali metal impurity levels provided accurate $\mathrm{Li}, \mathrm{Na}$ and $\mathrm{K}$ determinations of ARG-1 glass with no blank corrections required. However, it is good laboratory practice to always prepare a dissolution blank from every new bottle of $\mathrm{CsOH}$ and analyze it before the $\mathrm{CsOH}$ reagent is used for the fusions. This practice will detect impurities before they corrupt a set of analyses.

Table 5 shows the levels of impurities after $2.75 \mathrm{~g}$ of $\mathrm{CsOH}$ is fused in a zirconium crucible and then serially diluted to $2750 \mathrm{ml}$. This dilution factor was also used for the glass dissolutions, so the impurity concentrations in the table equal the positive bias, if any, introduced by $\mathrm{CsOH}$. 
WSRC-TR-98-00124

Page 8 of 16

Rev. 0

\section{ICP-AES Calibration Standards}

Elemental analyses discussed in this report were obtained after calibrating the ICP-AES spectrometer with multi-element standards in $2 \% \mathrm{HNO}_{3}$. Accurate analyses of ARG-1 glass with both $\mathrm{CsOH}$ and $\mathrm{Na}_{2} \mathrm{O}_{2}$ fusions indicate that it may be unnecessary to prepare calibration standards in the fusion matrices and in $2 \% \mathrm{HNO}_{3}$. This result has practical implications for the ICP-AES laboratory. Standards matrix matched to the fusion dissolution as well as $2 \% \mathrm{HNO}_{3}$ standards are used in some laboratories. Considerable time is consumed calibrating the ICP-AES with two sets of standards. Implementation of the $\mathrm{CsOH}$ method would increase efficiency in spectroscopic laboratories by analyzing only one solution per sample and by calibrating on only one set of standards.

\section{Applications to the DWPF}

The $\mathrm{CsOH}$ fusion method has clear convenience and speed advantages that make it an attractive candidate for dissolving DWPF process control glass samples. Glass shards from crucible melts would be dissolved to avoid having to crush the glass. The single dissolution scheme would replace the dual scheme currently used, $\mathrm{Na}_{2} \mathrm{O}_{2}-\mathrm{NaOH}$ fusion and microwave-assisted acid dissolution with $\mathrm{HNO}_{3}-\mathrm{HF}-\mathrm{H}_{3} \mathrm{BO}_{3}-\mathrm{HCl}$.

The DWPF will evaluate in 1998 a proposed alternative to glass analyses. Previous experiments performed in SRTC (refs. 5,6) and the DWPF laboratory (ref. 7) indicate that sample vial inserts do not significantly corrupt the proportion of sludge and frit in Slurry Mix Evaporator and Melter Feed Tank samples. Vial inserts are much more convenient to handle in a shielded cell facility than $14 \mathrm{ml}$ sample vials now used. Slurry samples are taken in pre-weighed Teflon or zirconium inserts with a volume of about $3 \mathrm{ml}$ and then decanted into a plastic bottle or crucible. A particularly convenient dissolution method is to add $\mathrm{HF}-\mathrm{HCl}$ directly to the slurry (ref. 5). Slurry dissolutions avoid the considerable time and trouble needed to convert melter feed into glass. To convert slurry analyses into the corresponding glass analyses, a factor is used from the weight $\%$ calcined or vitrified solids in the slurry. Most of the controversy over adopting this approach has involved the slurry dissolutions and the factor needed to convert slurry elemental analyses to glassbased analyses.

Another scheme has been developed for DWPF process control glass analyses that should be considered, at least as a complementary or back-up method to the vial insert-slurry dissolution scheme. One reason that alternatives to glass dissolutions were sought in the first place is that converting melter feed to glass has always been slow and cumbersome to perform remotely. Slurry samples taken in $14 \mathrm{ml}$ vials must be quantitatively transferred to a Pt crucible to avoid corrupting the ratio of frit to sludge in the feed. The vial is rinsed with several volumes of water to make the transfer. Before the slurry can be vitrified, it is dried to a powder to avoid splattering when the crucible is placed in the $1100^{\circ} \mathrm{C}$ furnace. 
WSRC-TR-98-00124

Page 9 of 16

Rev. 0

The time needed to evaporate the water from the slurry is a significant percentage of total analysis time. The glass is then crushed to a fine powder and dissolved with two different methods prior to the elemental analysis.

The alternative scheme starts with a new way to take process samples. The vial insert approach is incompatible with converting the feed into glass. Teflon and $\mathrm{Zr}$ cannot withstand the $1100^{\circ} \mathrm{C}$ vitrification temperature. Even if vial inserts made from Pt were used, the alkali fusion methods needed to rapidly dissolve the resulting glass would also dissolve the Pt insert and crucible. A way is needed to collect and dispense a small volume of slurry without adding either rinse water or the sample container to the crucible.

Disposable $10 \mathrm{ml}$ plastic syringes manufactured by Becton Dickinson \& Company can be modified into sample devices that conveniently and efficiently dispense silurries into crucibles for analysis (ref. 8). The syringes have nearly the same inner diameter as $3 \mathrm{ml}$ inserts, so cutting them off at the proper length yields the same volume as inserts. To make a practical sample vessel, the cut off syringe barrel is then fitted into the top half of a cut off $25 \mathrm{ml}$ plastic scintillation vial. The screw threads on scintillation vials are identical to the threads on $14 \mathrm{ml}$ glass vials. This means that septum caps that fit on $14 \mathrm{ml}$ glass vials also fit perfectly on the scintillation vials. Combining the syringe and scintillation vial effectively creates a vial or bottle with a sliding bottom to completely transfer slurries from the syringe. Another way of looking at the syringe device is as an insert with a sliding bottom. The syringe bottle would be filled with sample using the Hydragard ${ }^{\mathrm{TM}}$ valve just as $14 \mathrm{ml}$ glass vials are filled now.

The syringe system provides a fast and convenient way of converting $3 \mathrm{ml}$ of slurry into glass for analysis. Since the syringe transfer requires no rinse water, the $3 \mathrm{ml}$ of slurry can be dried and vitrified in a Pt crucible in about one hour. The thin glass disk would be shattered with a pestle into shards in the Pt crucible. A portion of the shards would then be transferred to $\mathrm{Zr}$ or Ni crucible and dissolved with the $\mathrm{CsOH}$ fusion method.

The syringe system also provides a convenient way of combining weight \% solids after simple drying and after vitrification with the dissolution procedure. The dry powder and glass that form in the crucible would be weighed before starting the dissolutions. Combining analyses is always a good thing, but is particularly desirable in shielded cells where cell space is at a premium and manpower allocation is important. 
WSRC-TR-98-00124

Page 10 of 16

Rev. 0

In summary, syringe bottles allow melter feed samples to be vitrified quickly and conveniently. The glass would then be shattered to shards and dissolved with $\mathrm{CsOH}$ to provide solutions for elemental analyses. This approach has five significant advantages over the scheme currently used in the DWPF:

1. Melter feed slurry would be rapidly dried and vitrified in about one hour versus several hours now required to evaporate excess rinse water and then make glass.

2. Glass shards would be dissolved to avoid having to crush glass to a fine powder with a motorized mixer mill.

3. $\mathrm{CsOH}$ fusion dissolutions would replace the dual dissolution scheme of $\mathrm{Na}_{2} \mathrm{O}_{2}-\mathrm{NaOH}$ fusion and microwave-assisted acid dissolution with $\mathrm{HNO}_{3}-\mathrm{HF}-\mathrm{H}_{3} \mathrm{BO}-\mathrm{HCl}$.

4. HF is not required. The safety and chemistry problems (formation of insoluble metal fluorides) associated with using HF would be eliminated.

5. Weight $\%$ solids after drying and vitrifying the melter feed would be integrated with the dissolution work-up.

\section{Applications to SRTC and the Commercial Glass Industry}

It is a shame that this method did not occur to us 15 years ago. Hundreds of glass samples were dissolved with two different methods to support DWPF development projects. Most of these samples could have been analyzed more efficiently using the $\mathrm{CsOH}$ method. DWPF development samples have slowed to a trickle. However, important DWPF support samples are still being generated in the SRTC shielded cells. The $\mathrm{CsOH}$ method will be applied in SRTC whenever possible. No single dissolution method is applicable to all glasses and to all elements in glass. More experiments will be performed with other glasses to establish method versatility.

The ability of $\mathrm{CsOH}$ to attack the silica matrix in glass should be of general interest to the commercial glass industry. The need to use multiple dissolutions is also a problem for glass producers. We have been contacted by glass industry analytical chemists about possible applications of the $\mathrm{CsOH}$ fusion method to their glass samples. 
WSRC-TR-98-00124

Page 12 of 16

Rev. 0

\section{Table 1}

\section{Comparison of $\mathrm{CsOH}$ and $\mathrm{Na}_{2} \mathrm{O}_{2}$ Fusions For Elemental Analysis of ARG-1 Glass Standard Powder}

\begin{tabular}{|c|c|c|c|c|c|}
\hline \multirow{3}{*}{$\begin{array}{l}\text { Element } \\
\text { AI } \\
\text { B }\end{array}$} & \multirow{2}{*}{$\begin{array}{l}\text { Reference } \\
\text { Value(wt.\%) } \\
2.50\end{array}$} & \multicolumn{2}{|c|}{$\begin{array}{l}\text { CsOH Fusion of } \\
\text { Glass Powder (wt\%) }\end{array}$} & \multicolumn{2}{|c|}{$\begin{array}{l}\mathrm{Na}_{2} \mathrm{O}_{2} \text { Fusion of } \\
\text { Glass Powder (wt } \%)^{2}\end{array}$} \\
\hline & & 2.36 & $\sigma=0.01$ & 2.37 & $\sigma=0.02$ \\
\hline & 2.69 & 2.66 & 0.01 & 2.63 & 0.03 \\
\hline $\mathbf{B a}$ & 0.079 & 0.071 & 0.006 & 0.071 & 0.002 \\
\hline Ca & 1.02 & 1.00 & 0.01 & 1.17 & 0.01 \\
\hline $\mathrm{Fe}$ & 9.79 & 9.99 & 0.06 & 10.0 & 0.07 \\
\hline $\mathbf{K}$ & 2.26 & 2.32 & 0.08 & 2.32 & 0.22 \\
\hline $\mathbf{L i}$ & 1.49 & 1.51 & 0.01 & 1.54 & 0.01 \\
\hline Mg & 0.52 & 0.51 & 0.01 & 0.52 & 0.01 \\
\hline $\mathbf{M n}$ & 1.46 & 1.42 & 0.01 & 1.42 & 0.01 \\
\hline $\mathrm{Na}$ & 8.52 & 8.61 & 0.05 & b. & b. \\
\hline $\mathbf{N i}$ & 0.827 & 0.795 & 0.02 & 0.808 & 0.008 \\
\hline $\mathbf{P}$ & 0.11 & 0.10 & 0.01 & 0.10 & 0.01 \\
\hline $\mathbf{S i}$ & 22.4 & 22.1 & 0.12 & 22.0 & 0.13 \\
\hline $\mathbf{T i}$ & 0.690 & 0.692 & 0.011 & 0.696 & 0.002 \\
\hline Zn & 0.016 & 0.015 & 0.001 & 0.015 & 0.001 \\
\hline
\end{tabular}

a. Average values and standard deviations based on 6 replicate analyses

b. Na not measured because it is introduced in the alkali fusion reagent 
WSRC-TR-98-00124

Page 13 of 16

Rev. 0

\section{Table 2}

\section{Comparison of Elemental Analyses of ARG-1 Powder following $\mathrm{CsOH}$ Fusions carried out at $500^{\circ} \mathrm{C}$ and $750^{\circ}$}

\begin{tabular}{|c|c|c|c|c|c|}
\hline \multirow{2}{*}{$\frac{\text { Element }}{\text { Al }}$} & \multirow{2}{*}{$\begin{array}{l}\text { Reference } \\
\text { Value(wt.\%) } \\
2.50\end{array}$} & \multicolumn{2}{|c|}{$\begin{array}{l}\quad 500^{\circ} \mathrm{C} \\
\text { CsOH Fusion of } \\
\text { Glass Powder }(\mathrm{wt} \%)^{\mathrm{a}}\end{array}$} & \multicolumn{2}{|c|}{$\begin{array}{l}\quad 750^{\circ} \mathrm{C} \\
\text { CsOH Fusion of } \\
\text { Glass Powder }(w t \%)^{\text {a. }}\end{array}$} \\
\hline & & 2.36 & $\sigma=0.01$ & 2.36 & $\sigma=0.01$ \\
\hline B & 2.69 & 2.69 & 0.01 & 2.66 & 0.01 \\
\hline $\mathbf{B a}$ & 0.079 & 0.071 & 0.008 & 0.071 & 0.006 \\
\hline $\mathbf{C a}$ & 1.02 & 1.01 & 0.01 & 1.00 & 0.01 \\
\hline $\mathrm{Fe}$ & 9.79 & 10.0 & 0.03 & 9.99 & 0.06 \\
\hline $\mathbf{K}$ & 2.26 & 2.30 & 0.11 & 2.32 & 0.08 \\
\hline $\mathbf{L i}$ & 1.49 & 1.51 & 0.01 & 1.51 & 0.01 \\
\hline Mg & 0.52 & 0.51 & 0.01 & 0.51 & 0.01 \\
\hline Mn & 1.46 & 1.43 & 0.01 & 1.42 & 0.01 \\
\hline $\mathbf{N a}$ & 8.52 & 8.69 & 0.08 & 8.61 & 0.05 \\
\hline $\mathbf{N i}$ & 0.827 & 0.812 & 0.05 & 0.795 & 0.02 \\
\hline $\mathbf{P}$ & 0.11 & 0.10 & 0.01 & 0.10 & 0.01 \\
\hline $\mathbf{S i}$ & 22.4 & 22.2 & 0.12 & 22.1 & 0.12 \\
\hline Ti & 0.690 & 0.697 & 0.011 & 0.692 & 0.011 \\
\hline Zn & 0.016 & 0.015 & 0.001 & 0.015 & 0.001 \\
\hline
\end{tabular}

a. Average values and standard deviations based on 6 replicate analyses 
WSRC-TR-98-00124

Page 14 of 16

Rev. 0

\section{Table 3}

\section{Comparison of $\mathrm{CsOH}$ and $\mathrm{Na}_{2} \mathrm{O}_{2}$ Fusions For Elemental Analysis of ARG-1 Glass Standard Pellets}

\begin{tabular}{|c|c|c|c|c|c|}
\hline \multirow{2}{*}{$\begin{array}{l}\text { Element } \\
\text { Al }\end{array}$} & \multirow{2}{*}{$\begin{array}{l}\text { Reference } \\
\text { Value(wt.\%) } \\
2.50\end{array}$} & \multicolumn{2}{|c|}{$\begin{array}{l}\text { CsOH Fusion of } \\
\text { Glass Pellets (wt } \%)^{a}\end{array}$} & \multicolumn{2}{|c|}{$\begin{array}{l}\mathrm{Na}_{2} \mathrm{O}_{2} \text { Fusion of } \\
\text { Glass Pellets }(\mathrm{wt} \%)^{\mathrm{a}}\end{array}$} \\
\hline & & 2.37 & $\sigma=0.04$ & 2.38 & $\sigma=0.01$ \\
\hline $\mathbf{B}$ & 2.69 & 2.65 & 0.05 & 2.63 & 0.03 \\
\hline $\mathbf{B a}$ & 0.079 & 0.073 & 0.003 & 0.071 & 0.005 \\
\hline $\mathbf{C a}$ & 1.02 & 1.01 & 0.01 & 1.03 & 0.04 \\
\hline $\mathbf{F e}$ & 9.79 & 10.00 & 0.12 & 9.97 & 0.08 \\
\hline $\mathbf{K}$ & 2.26 & 2.29 & 0.10 & 2.37 & 0.16 \\
\hline Li & 1.49 & 1.52 & 0.02 & 1.53 & 0.01 \\
\hline Mg & 0.52 & 0.51 & 0.01 & 0.50 & 0.01 \\
\hline Mn & 1.46 & 1.43 & 0.02 & 1.41 & 0.01 \\
\hline $\mathbf{N a}$ & 8.52 & 8.68 & 0.10 & b. & b. \\
\hline $\mathbf{N i}$ & 0.827 & 0.795 & 0.02 & 0.808 & 0.008 \\
\hline $\mathbf{P}$ & 0.11 & 0.10 & 0.01 & 0.10 & 0.01 \\
\hline Si & 22.4 & 22.4 & 0.25 & 21.9 & 0.13 \\
\hline $\mathbf{T i}$ & 0.690 & 0.703 & 0.011 & 0.696 & 0.002 \\
\hline $\mathbf{Z n}$ & 0.016 & 0.016 & 0.004 & 0.016 & 0.002 \\
\hline
\end{tabular}

a. Average values and standard deviations based on 6 replicate analyses

b. Na not measured because it is introduced in the alkali fusion reagent 
WSRC-TR-98-00124

Page 15 of 16

Rev. 0

\section{Table 4}

\section{Elemental Analyses of ARG-1 Glass Shards following $\mathrm{CsOH}$ Fusions}

\begin{tabular}{|c|c|c|c|}
\hline \multirow{2}{*}{$\frac{\text { Element }}{\text { Al }}$} & \multirow{2}{*}{$\begin{array}{l}\text { Reference } \\
\text { Value(wt.\%) } \\
2.50\end{array}$} & \multicolumn{2}{|c|}{$\begin{array}{l}\text { CsOH fusion of } \\
\text { Glass Shards (wt } \%)^{a}\end{array}$} \\
\hline & & $\mathbf{2 . 3 5}$ & $\sigma=0.01$ \\
\hline B & 2.69 & 2.65 & 0.01 \\
\hline Ba & 0.079 & 0.070 & 0.005 \\
\hline $\mathbf{C a}$ & 1.02 & 0.98 & 0.02 \\
\hline $\mathbf{F e}$ & 9.79 & 9.92 & 0.03 \\
\hline $\mathbf{K}$ & 2.26 & 2.37 & 0.10 \\
\hline $\mathbf{L i}$ & 1.49 & 1.50 & 0.01 \\
\hline Mg & 0.52 & 0.51 & 0.01 \\
\hline Mn & 1.46 & 1.41 & 0.01 \\
\hline $\mathbf{N a}$ & 8.52 & 8.57 & 0.10 \\
\hline $\mathrm{Ni}$ & 0.827 & 0.795 & 0.02 \\
\hline $\mathbf{P}$ & 0.11 & 0.10 & 0.01 \\
\hline Si & 22.4 & 22.4 & 0.25 \\
\hline $\mathbf{T i}$ & 0.690 & 0.703 & 0.011 \\
\hline $\mathbf{Z n}$ & 0.016 & 0.016 & 0.004 \\
\hline
\end{tabular}

a. Average values and standard deviations based on 6 replicate analyses 
WSRC-TR-98-00124

Page 16 of 16

Rev. 0

\section{Table 5}

\section{Impurity Concentrations ${ }^{\mathrm{a}}$ in CsOH Fusion Blanks}

\begin{tabular}{lll} 
Element & & Impurity (wt\%) \\
\cline { 1 - 1 } AI & & $<\mathbf{0 . 0 3}$ \\
B & & $<\mathbf{0 . 0 2}$ \\
Ba & $<\mathbf{0 . 0 1}$ \\
Ca & $<\mathbf{0 . 0 4}$ \\
Fe & $<\mathbf{0 . 0 1}$ \\
K & $<\mathbf{0 . 0 2}$ \\
Li & $<\mathbf{0 . 0 1}$ \\
Mg & $<\mathbf{0 . 0 1}$ \\
Mn & $<\mathbf{0 . 0 1}$ \\
Na & $\mathbf{0 . 0 5}$ \\
Ni & $<\mathbf{0 . 0 4}$ \\
P & $<\mathbf{0 . 0 4}$ \\
Si & $<\mathbf{0 . 0 2}$ \\
Ti & $\mathbf{0 . 0 3}$ \\
Zn & $<\mathbf{0 . 0 4}$
\end{tabular}

a. The blank was prepared and diluted exactly as samples. Since a 10,000 fold dilution was used, the impurities measured in $\mathrm{mg} / \mathrm{L}$ of the blank solution also correspond to weight $\%$ impurity in the analyses. 